\title{
Identification of the gene coding for the Endo B murine cytokeratin and its methylated, stable inactive state in mouse nonepithelial cells
}

\author{
Robert G. Oshima, Katrina Trevor, Lynne H. Shevinsky, Oliver A. Ryder, ${ }^{1}$ and Grace Ceceña \\ Cancer Research Center, La Jolla Cancer Research Foundation, La Jolla, California, 92037 USA; ${ }^{1}$ Research Department, San \\ Diego Zoo, San Diego, California 92112 USA
}

\begin{abstract}
The Endo B type-I keratin intermediate filament protein is first expressed at the 4- to 8-cell stage of mouse development. In the adult, its expression is restricted to a variety of simple epithelial cell types. To investigate the mechanisms responsible for the restricted expression of Endo B, the gene coding for Endo B has been identified from among the five different Endo B genes found in the mouse genome by Southern hybridization analysis and cloning all or part of four of the genes. Nuclear run-on experiments demonstrate that Endo B expression is regulated at the level of transcription. The $5^{\prime}$ end of the active gene, designated Endo $\beta 1$, was found to be highly methylated and in a relatively nuclease-resistant chromatin conformation in fibroblasts and myoblasts that do not express Endo B, but undermethylated and relatively sensitive to nuclease digestion in endodermal cells or F9 embryonal carcinoma cells. The inactive state of the Endo B $\beta 1$ gene in fibroblast appears to be very stable, because somatic cell hybrids formed by the fusion of HeLa cells, which express the homologous human protein, keratin 18, and mouse fibroblasts, continue to express keratin 18 but do not activate Endo B expression. Similarly, the fusion of mouse endodermal cells and fibroblasts results in hybrids that do not extinguish Endo B expression. These results suggest that Endo B transcription is limited by two different mechanisms. In somatic cells such as fibroblasts or myoblasts, expression may be restricted by methylation and a stable, nonpermissive transcriptional state. However, in embryonal carcinoma cells, the Endo B $\beta 1$ gene is undermethylated and in a relatively nuclease-sensitive conformation, but it is restricted by an additional, negative regulatory mechanism.
\end{abstract}

[Key Words: Keratin; genes; methylation; embryonal carcinoma; DNase; chromatin somatic cell hybrids; pseudogenes]

Received January 27, 1988; accepted March 17, 1988.

Endo B (Oshima 1981) (also referred to as cytokeratin D; Franke et al. 1981a,b/ and its homologous human form, keratin 18 (K18) are type-I keratin intermediate filament proteins (for reviews on intermediate filament proteins, see Lazarides 1980, 1982; Steinert and Parry 1985) found in a variety of simple epithelial tissues (Kemler et al. 1981; Moll et al. 1982; Schiller et al. 1982). Endo B and Endo A, its complementary type-II keratin subunit (Brulet et al. 1980; Oshima 1982), are first expressed at the 4-8 cell stage of mouse embryogenesis but are limited to trophectodermal and extraembryonic endodermal tissues of the blastocyst stage embryo (Brulet et al. 1980; Oshima et al. 1983). Murine embryonal carcinoma (EC) cells express little or no Endo B or Endo A unless the cells are permitted to differentiate to extraembryonic endoderm (Oshima 1981, 1982). The in vitro differentiation of EC cell lines provides a convenient system for investigating early developmental cellular transitions that would be difficult otherwise.

Two aspects of the regulation of Endo B expression are of particular interest. The first is the mechanism respon- sible for the expression of the same gene in a restricted but relatively large number of differentiated cell types as diverse as parietal endoderm and liver (Trevor and Oshima 1985|. In this respect, the regulation of Endo B might be considered intermediate between specialized genes expressed in only a very few cell types such as $\beta$ globins, immunoglobulins, $\alpha$-fetoprotein, or epidermal keratins and ubiquitously expressed genes such as those for many metabolic functions. The second aspect is its activation and expression at very early times in development. Endo A and B are among the first gene products differentially expressed during mouse development (Chisholm and Houliston 1987).

In this study we identify the single Endo B gene among the five found in the mouse genome that is likely responsible for expression in diverse permissive cell types and show that it is regulated at the transcriptional level. Furthermore, we provide evidence that in differentiated cells that do not express Endo B, the gene is in a stable, inactive state characterized by a highly methylated and relatively nuclease-resistant chromatin structure. 


\section{Results and discussion}

\section{Endo $B$ genes in rodents and primates}

The tissue distribution of Endo B and its homologous human form, Kl8, are very similar, if not identical (Moll et al. 1982; Schiller et al. 1982) in the adult. However, the expression of $\mathrm{K} 18$ and $\mathrm{K} 8$ in human EC cells (Damjanov and Andrews 1983; Damjanov et al. 1985; R.G. Oshima, unpubl.|, suggests that human EC cells and perhaps human embryonic cells differ from mouse EC cells and their respective mouse embryonic counterparts in this respect. Previously, we have estimated that the mouse and human genomes contain $\sim 5$ and 20 copies, respectively, of genes very similar to Endo $\mathrm{B}$ (Trevor and Oshima 1985). The larger number of genes similar to Endo B found in human DNA may reflect a difference in early developmental expression, because expression of $\mathrm{K} 18$ in the equivalent of the mouse inner cell mass could provide a target for retrovirus-mediated pseudogene generation in the germ line (Linial 1987). To determine whether the large number of human genes similar to Endo $B$ is characteristic of primates in general, a number of mammalian DNAs was screened by the method of Southern (1975) for sequences similar to Endo B under conditions that do not permit detection of related epidermal keratin or other intermediate filament genes. Figure 1 shows that mouse, rat, horse, and whale DNAs

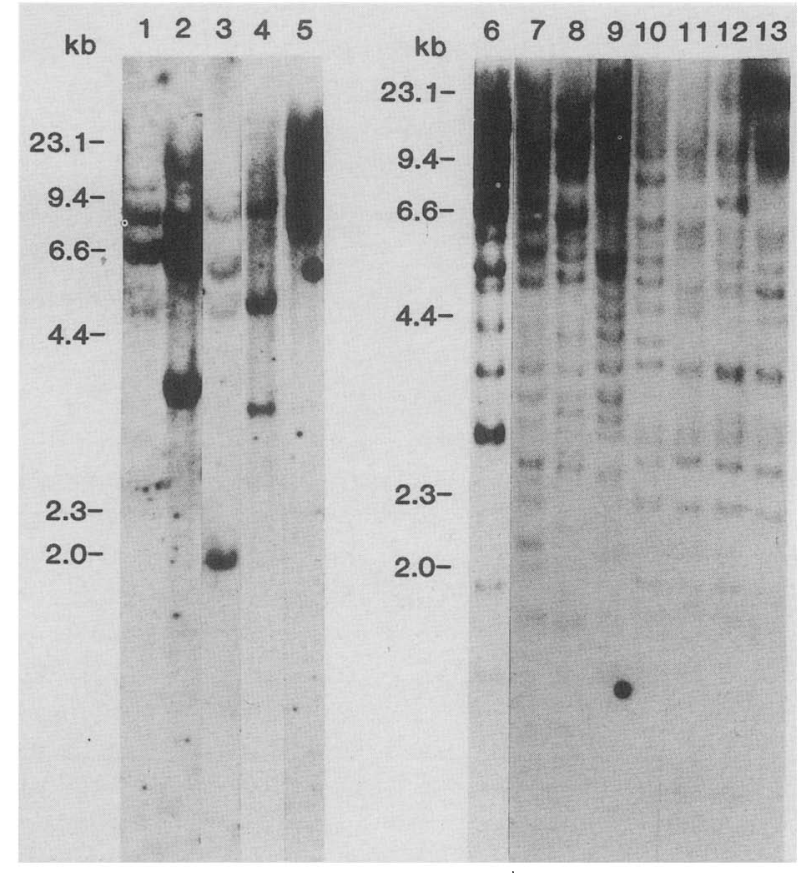

Figure 1. Primates have many genes closely related to Endo B. DNAs from the indicated species were digested with BamHI, separated by agarose gel electrophoresis, transferred to nitrocellulose, and hybridized to nick-translated Endo B cDNA. Final washes were in $0.1 \times \mathrm{SSC}, 0.1 \%$ SDS at $50^{\circ} \mathrm{C}$, which eliminates detectable hybridization to related epidermal keratin sequences. (1) Mouse; (2) rat; (3) horse; (4) sperm whale; (5) lemur; (6) potto; (7) saki monkey; (8) spider monkey; (9) macaque; (10) orangutan; (11) chimpanzee; (12) gorilla; (13) human. Size markers are indicated on the left of each panel $(\mathrm{kb})$. have a relatively small number of fragments that hybridize strongly to the Endo B cDNA, whereas all primates, with the possible exception of lemur, have a much larger number of similar sequences. These animals are representatives of evolutionarily diverse primate lineages, including prosimians (potto), old world monkeys (macaque), new world monkeys (saki and spider monkeys), great apes (orangutan, chimpanzee, and gorilla), and humans. This suggests that the duplication of Endo B-like genes occurred early in primate evolu-

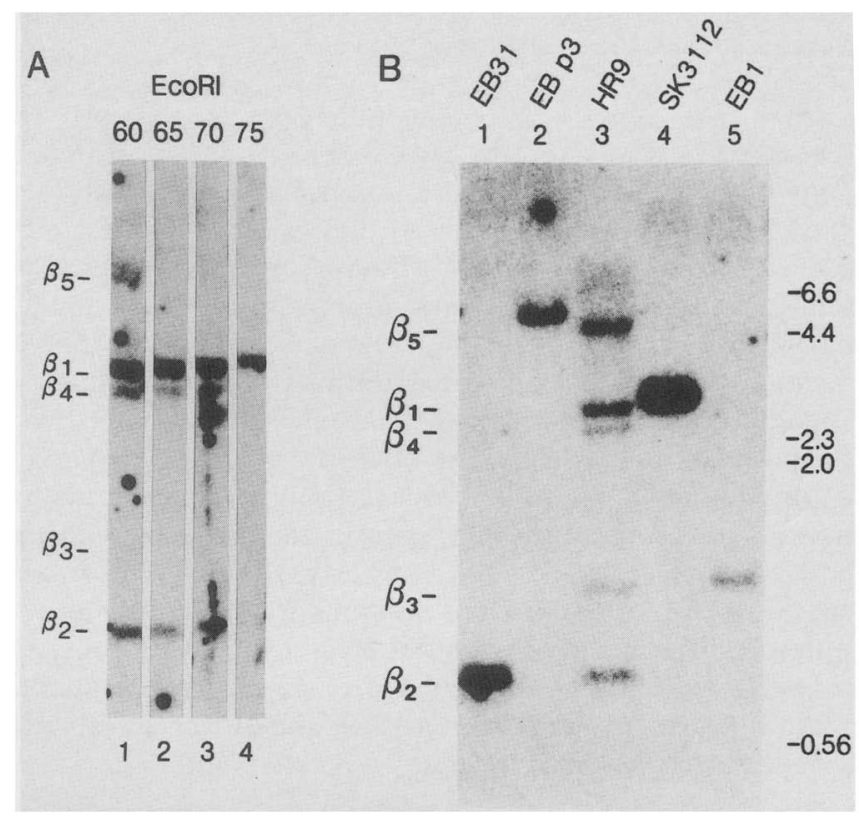

Figure 2. Comparison of cloned genes to mouse endogenous Endo B genes. (A) Multiple aliquots of $10 \mu \mathrm{g}$ of F9 mouse genomic DNA were digested with EcoRI, separated in an agarose gel, transferred to nitrocellulose, and hybridized to a sense RNA probe representing the first $461 \mathrm{bp}$ of the Endo B cDNA. Strips of the filter were hybridized together but washed independently in $0.1 \times$ SSC, $0.1 \%$ SDS, at the temperature indicated at the top of the panel. The individual Endo B genes are indicated at the left of the panel. An autoradiographic image obtained with an intensifier screen is shown. Note that after washing at $75^{\circ} \mathrm{C}$ (lane 4), only the signal of the $\beta 1$ gene is still detectable. $(B)$ Phage $\lambda$ DNAs containing cloned Endo $B$ genes (EB31, lane 1; EBp3, lane 2; EB1, lane 5), plasmid DNA containing the $5^{\prime}$ end of the Endo B $\beta 1$ gene (SK3112, lane 4), and mouse genomic DNA isolated from a near diploid parietal endodermal cell line (HR9, lane 3) were digested with EcoRI, separated in an agarose mini gel, transferred to nitrocellulose, hybridized to the same probe used in panel $A$, and washed in $0.1 \times$ SSPE, $0.1 \%$ SDS at $50^{\circ} \mathrm{C}$. The probe contains all of exon $\mathrm{I}$ and only nine nucleotides of exon II sequences of the $\beta 1$ gene. An autoradiographic image obtained with an intensifier screen is shown. Carrier undigested Escherichia coli DNA (2 $\mu \mathrm{g})$ was added to $\sim 60 \mathrm{pg}$ of phage DNA or $15 \mathrm{pg}$ of plasmid DNA before loading. Two micrograms of mouse genomic DNA were used. The Endo $B$ genes are indicated on the left, and size markers (in $\mathrm{kb} /$ are indicated on the right. The variation in the rate of migration of the hybridizing band of EBp3 DNA (lane 2) and the endogenous $\beta 5$ Endo $B$ gene (lane 3 ) is probably due to effects of the undigested carrier DNA. 
tion. The presence of processed pseudogenes for Endo A (Vasseur et al. 1985) and Endo B (see below) and the evidence for expression of only a single Endo B gene (Trevor and Oshima 1985) in both mice and humans (Kulesh and Oshima 1988) suggest that many of the hybridizing bands found in primate DNA may represent pseudogenes.

To identify which of the mouse Endo B genes might code for the expressed protein, Southern analysis was performed under increasing stringency. The results are shown in Figure 2A. After EcoRI-digested mouse DNA is hybridized with an RNA probe of the first 461 nucleotides of the Endo B cDNA and washed at $60^{\circ} \mathrm{C}$, five fragments are detected (lane 1), which are designated $\beta 1-\beta 5$. If replicate filters are washed at $65^{\circ} \mathrm{C}$ or $70^{\circ} \mathrm{C}$, only three of the fragments are detectable (lanes 2 and 3). At $75^{\circ} \mathrm{C}$, only a single hybridizing fragment is detected. This fragment, designated $\beta 1$, likely contains sequences most similar to the cDNA probe and suggests that it represents a part of the gene transcriptionally active in endodermal or liver cells. The same experiment performed on BamHI-digested mouse DNA resulted in a single detectable fragment of $\sim 6.5-\mathrm{kb}$ after washing at $70^{\circ} \mathrm{C}$ (data not shown).

Figure 2B compares the hybridization pattern of the endogenous Endo B genes to four genes that were isolated by cloning. Repeated screening of total genomic DNA libraries resulted in the isolation of the $\beta 2, \beta 3$, and $\beta 5$ genes. However, the $\beta 1$ gene, which was the best candidate for the active gene, was apparently underrepresented in these libraries (Table 1). Part of the $\beta 1$ gene was isolated by screening a library prepared from sizeselected DNA derived from a cell line that expressed Endo B. This resulted in the isolation of the $5^{\prime}$ end of the $\beta 1$ gene. Comparison of restriction enzyme maps of the $\beta 2, \beta 3$, and $\beta 5$ genes to that of the cDNA and Southern analysis using probes of the cDNA specific for the 5 ', middle, or $3^{\prime}$ portions of the cDNA revealed that none appeared to code for the Endo B cDNA (Fig. 3). The sizes of different hybridizing portions of the genes suggested that each might represent a pseudogene derived from reverse transcription of the Endo B RNA. Partial sequence analysis of two portions of the $\beta 2$ EB31 isolate confirmed this suggestion for the $\beta 2$ gene (data not shown). In contrast, the results of Southern analysis under very stringent conditions (Fig. 2A), DNA sequencing of the $\beta 1$ gene, and analyses of DNase-digested nuclei and the methylation state of the Endo B genes (see below) suggest that the $3-\mathrm{kb}$ EcoRI fragment of the $\beta 1$ gene represents part of the gene expressed in endodermal cells.

\section{Sequence of the $5^{\prime}$ end of Endo $B \beta 1$}

The sequence of the $5^{\prime}$ end of the Endo $B \quad \beta 1$ gene is shown in Figure 4. A 452-nucleotide portion of the gene was found to match the $5^{\prime}$ end of the Endo B cDNA exactly, including the 5 '-noncoding leader. In addition, the $3^{\prime}$ end of this region (nucleotide 451, AGGTAAGG) matches the sequence expected for a $5^{\prime}$ donor splice junction (Ohshima and Gotoh 1987). Thus, the underlined portion of the sequence represents the first exon of the Endo $B \beta 1$ gene, and the sequence following it represents part of the first intron. The first exon contains all but 9 nucelotides of the 461-nucleotide coding portion of the Endo B RNA probe used for screening and Southern hybridization.

Nuclease S1 protection analysis utilizing a fragment of the gene overlapping the expected $5^{\prime}$ end of the Endo B mRNA mapped the major transcriptional start site designated nucleotide +1 (Kulesh and Oshima 1988). The TATA box motif (ATATAA), found immediately upstream of the transcriptional start site of many eukaryotic genes, is found at nucleotide -27 . In comparison with the K18 gene (Kulesh and Oshima 1988 and unpubl.), eight regions of 8-11 identical nucleotides, but none longer than 11 nucleotides, are found. Some of these upstream regions may represent functionally important sequences because the TATA box is among them. No core sequences for the potential binding of the Spl transcription factor (GGGCGG, CCGCCC) (Dynan and Tjian 1985) are found, even though the K18 gene contains four such sites within $200 \mathrm{bp}$ upstream of the human gene (Kulesh and Oshima 1988). Two regions of short repeated sequences (nucleotides -816 and -448 ) and one imperfect long direct repeat (nucleotide -402) are found. One region within the first exon, starting at nucleotide 176 , may be of particular importance. Of 18 nucleotides of this region, 17 are identical to the tRNAbinding site of murine retroviruses that has been implicated in the block of viral RNA expression in murine EC cells (Barklis et al. 1986; Loh et al. 1987; Weiher et al. 1987).

Two portions of the sequence from nucleotide -129 to +1 and from nucleotide 121 to 251 are particularly GC rich $(68 \%$ and $71 \%$, respectively). In the first region, the dinucleotide CG is used almost as much as GC (10 to 12 times, respectively). The frequency of the CGs relative to GCs in the second region (58\%, $10 \mathrm{CGs}, 17 \mathrm{GCs})$ is similar to that of the sequence of the entire fragment (60\%, 56 CGs, 93 GCs). The 129 nucleotide region immediately upstream of the transcriptional start site of

Table 1. Summary of the isolated Endo B genes

\begin{tabular}{llllllrr}
\hline Gene & Isolate & Strain & Tissue & Vector & Library type & Plaques & Number \\
\hline$\beta 1$ & SK3112 & 129 Sv/J & HR9 cells & AZAP & 3-kb EcoRI & $4 \times 10^{5}$ & 5 \\
$\beta 2$ & EB31 & BALB/c & embryo & Charon 28 & MboI partial & $3 \times 10^{6}$ & 20 \\
& EB25 & C57BL/6 & T cell & EMBL3 & MboI partial & $5 \times 10^{5}$ & 2 \\
& EBp11 & BALB/c & embryo & Charon 4A & EcoRI partial & $6 \times 10^{5}$ & 1 \\
$\beta 3$ & EB1 & 129 & liver & EMBL3A & MboI partial & $6 \times 10^{5}$ & 11 \\
$\beta 5$ & EBp3 & BALB/c & embryo & Charon 4A & EcoRI partial & $6 \times 10^{5}$ \\
\hline
\end{tabular}


Oshima et al.

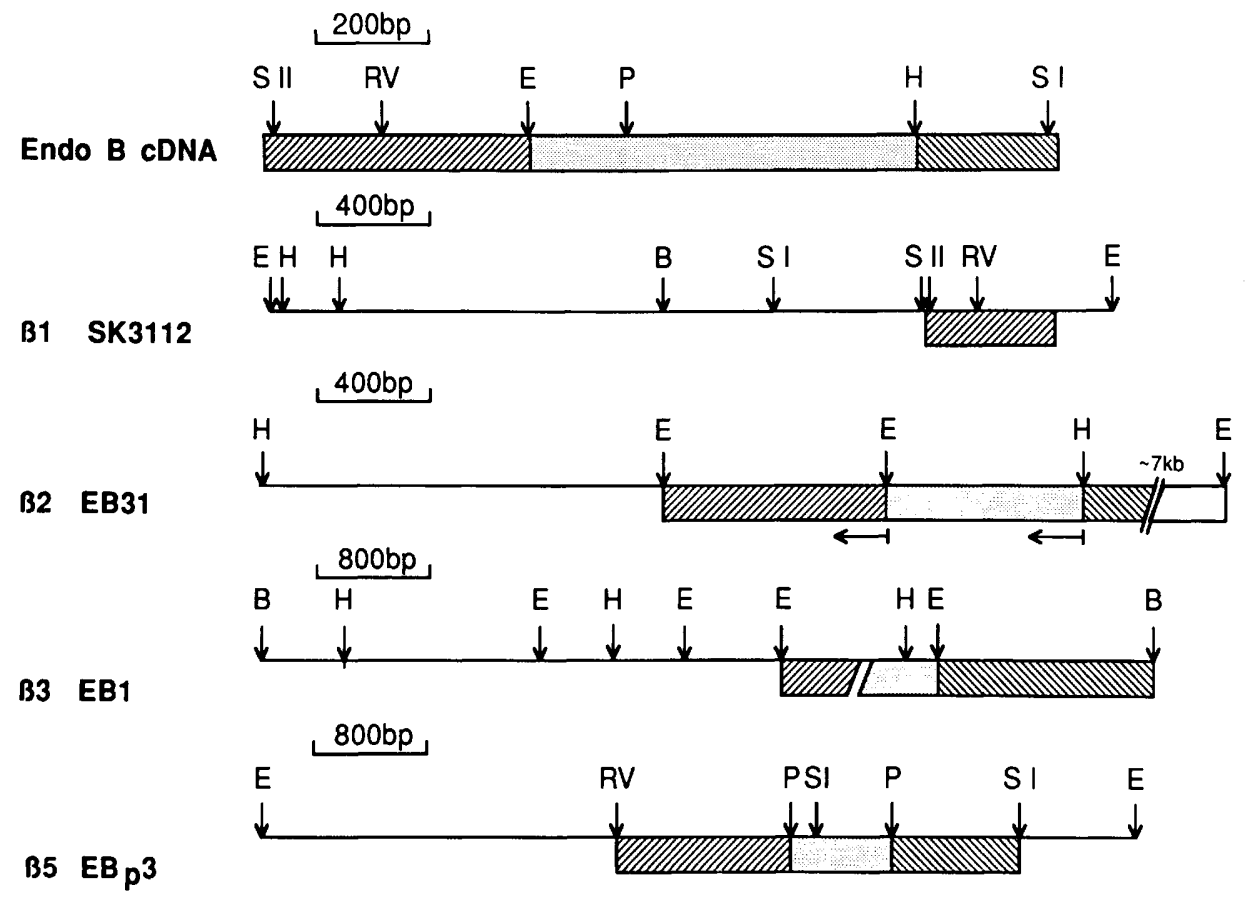

Figure 3. Restriction maps of the isolated Endo B genes. Left and right cross-hatched and stippled regions of the Endo B cDNA and genomic fragments indicate the portions used as probes and their respective hybridizing fragments. Only hybridizing portions of the genomic fragments of $\beta 2 \mathrm{~EB} 31, \beta 3 \mathrm{EB1}$, and $\beta 5 \mathrm{EBp} 3$ are shown. All three also contain additional unmapped flanking sequences. Enzymes shown are BamHI (B); EcoRI (E); PstI (P); EcoRV (RV); SstI (SI); and SstII (SII). The broken portion of the fragment of $\beta 2$ EB31 indicates the approximate portion of the $7-\mathrm{kb}$ fragment presumed to be responsible for the hybridization with the indicated probe and fragment. The broken EcoRI fragment of $\beta 3 \mathrm{EBl}$ indicates that this fragment hybridized to both the $5^{\prime}$ and middle portion cDNA probes. The arrow beneath the map of $\beta 2$ EB31 indicates the direction and approximate number of bases sequenced to confirm the pseudogene structure. The scale is indicated over the left portion of each map (bp).

the Endo B $\beta 1$ gene appears to qualify as an 'HTF island' (Bird 1986). Such regions are usually unique sequences of genomic DNA associated with the $5^{\prime}$ end of constitutively active genes and additionally are undermethy. lated.

\section{Endo $B$ is transcriptionally regulated}

Endo B is expressed in various simple epithelial cell types of the adult, parietal endodermal cells, and in EC cells that have differentiated to extraembryonic endodermal derivatives. Nuclear run-on assays were performed to determine whether the differential expression of Endo $B$ is due to transcriptional or post-transcriptional mechanisms. Figure 5 shows the results of hybridizing radioactive RNA made by isolated nuclei from several cell types to various target DNAs. This assay measures the transcriptional activity of endogenous genes by permitting elongation of previously initiated transcriptional complexes in the absence of new initiation (McKnight and Palmiter 1979). Positive signals for the transcription of the Endo B gene were found only in nuclei from F9 cells induced to differentiate by exposure to retinoic acid and in HR9 parietal endodermal cells but not in 984 myoblasts, undifferentiated F9 cells, or STO fibroblasts (data not shown). Actin transcription served as a positive control for all cell lines. The differentiation of F9 cells also results in increased transcription of Endo A, the type-II keratin with which Endo B polymerizes. In contrast, the large increase in proteoglycan PG19 RNA in retinoic acid-treated F9 cells (Grover et al. 1988) appears to be regulated post-transcriptionally.

The Endo $B$ B1 gene is differentially sensitive to DNase digestion

The chromatin states of the Endo B genes were investigated by digesting nuclei from various cell lines with varying concentrations of DNase I and analyzing the subsequently purified DNA by Southern analysis. Figure 6 shows the results of such an experiment for nuclei isolated from the MB4 endodermal and 984 myoblast cell lines. The Endo B $\beta 1$ gene in endodermal cells is much more sensitive to digestion than the $\beta 2, \beta 3$, or $\beta 5$ genes (Fig. 6, lanes 1-6). Weak hybridization precluded a firm conclusion concerning the sensitivity of the $\beta 4$ presumptive gene. The unlabeled, large fragment detected above the $\beta 5$ gene, which appears to be sensitive in both MB4 and 984 nuclei, does not hybridize to probes specific for the 5' end of the Endo B cDNA (see Figs. 2 and 7) and may represent the $3^{\prime}$ end of either the $\beta 1$ or $\beta 2$ genes. In contrast to the case in endodermal nuclei, the $\beta 1$ gene in 984 myoblast nuclei is relatively resistant to digestion. The $\beta 1$ gene was detectable even after diges- 


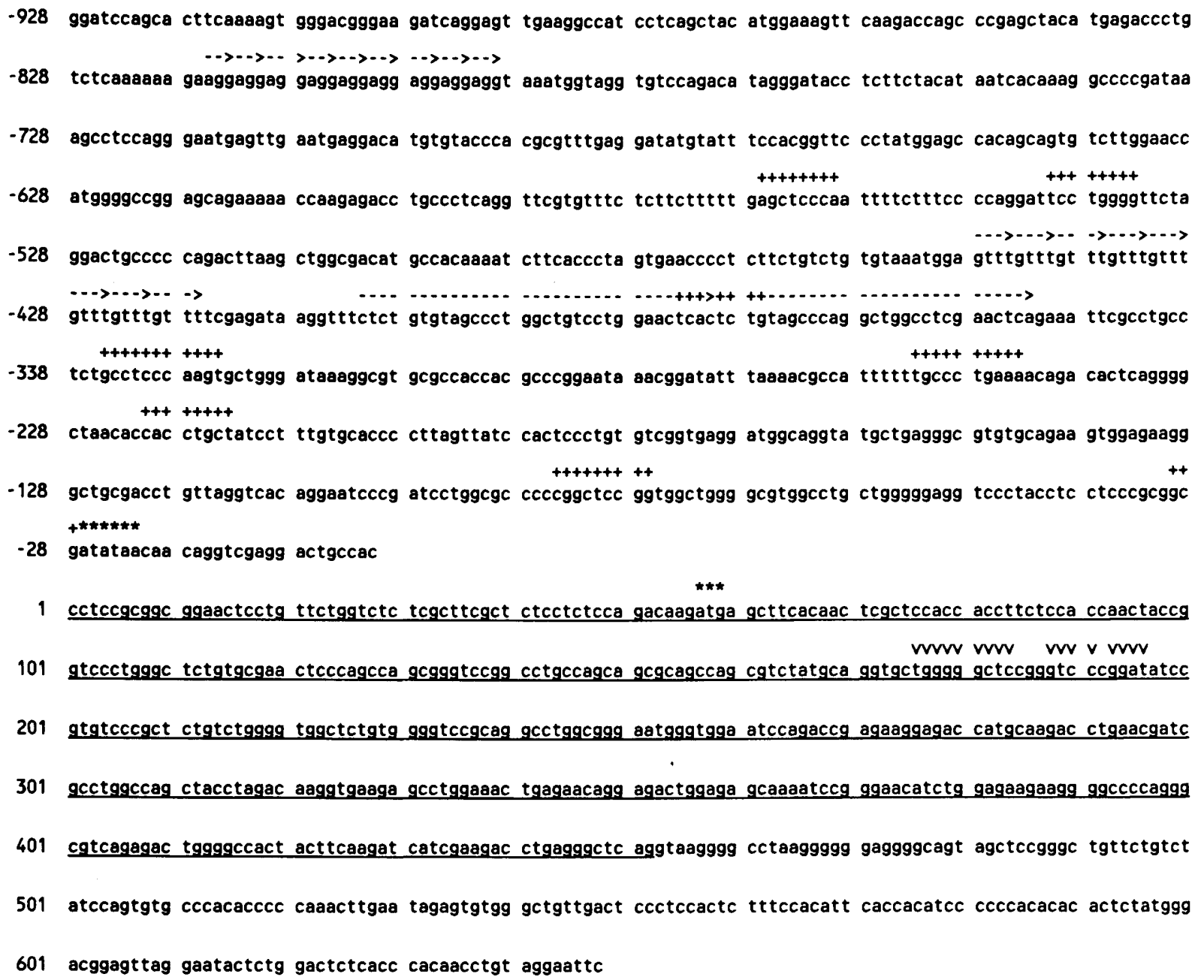

Figure 4. DNA sequence of the $5^{\prime}$ end of the Endo B $\beta 1$ gene. The sequence starts with BamHI site at -928 and ends at the EcoRI site at nucleotide 648. Nucleotide numbers on the left are relative to the start of the Endo B mRNA as +1 . Solid underlined sequence represents exon I, which is 452 nucleotides. The ATG translational start codon and a potential TATA box transcriptional regulatory element are indicated by asterisks $(*)$. Direct repeated sequences are indicated by dashed lines with arrow heads $(-->)$. Plus signs $(+)$ indicate the longest stretches of nucleotides identical in the homologous human K18 gene $5^{\prime}$-flanking region. The nucleotides of the first exon that are identical to the murine retroviral tRNA-binding site are indicated by arrowheads $(\mathbf{v})$.

tion with 6-7 $\mu \mathrm{g} / \mathrm{ml}$ of DNase, whereas in MB4 endodermal nuceli, digestion with even $3 \mu \mathrm{g} / \mathrm{ml}$ of nuclease resulted in loss of the $\beta 1$ signal. Similarly, the $\beta 1$ gene in HR9 parietal endodermal nuclei is sensitive, whereas the same gene in STO fibroblasts is resistant (data not shown). Additional experiments with nuclei isolated from PCC4F EC cells, F9 EC cells, or F9 cells treated with retinoic acid revealed that the $5^{\prime}$ end of the $\beta 1$ gene was completely digested by as little as $3 \mu \mathrm{g} / \mathrm{ml}$ of DNase $I$ in all three cell types, whereas the other fragments were more resistant (data not shown). The $\beta 1$ genes in both EC cells, which do not express Endo B, and endodermal cells are differentially sensitive to digestion, whereas the same gene in either fibroblasts or myoblasts is not.

\section{Differential methylation of the $\beta 1$ gene}

The methylation state of Endo B genes in the DNA of several cell types was investigated by Southern analysis utilizing the methylation-sensitive restriction enzyme HpaII and its methylation-insensitive isoschizomer $M s p I$. After digestion with EcoRI, DNAs from HR9 endodermal cells, F9 EC, STO fibroblasts, and 984 myoblasts were treated with either MspI or HpaII and analyzed by blot hybridization. The results are shown in Figure 7. In both HR9 DNA and undifferentiated F9 DNA, the signal for the $5^{\prime}$ end of the $\beta 1$ gene is completely lost upon digestion with HpaII. Within the portion of the $\beta 1$ gene that has been sequenced, there are 10 MspI/HpaII sites, six of which are located in the first exon. It is not possible by these results to ascertain directly the methylation status of the two individual MspI/HpaII sites located immediately upstream of the first exon (nucleotides -84 and -78 ) in the region of particularly high GC content. However, complete methylation of the four sites upstream of the transcriptional start site of the $\beta 1$ gene should have resulted in a detect- 


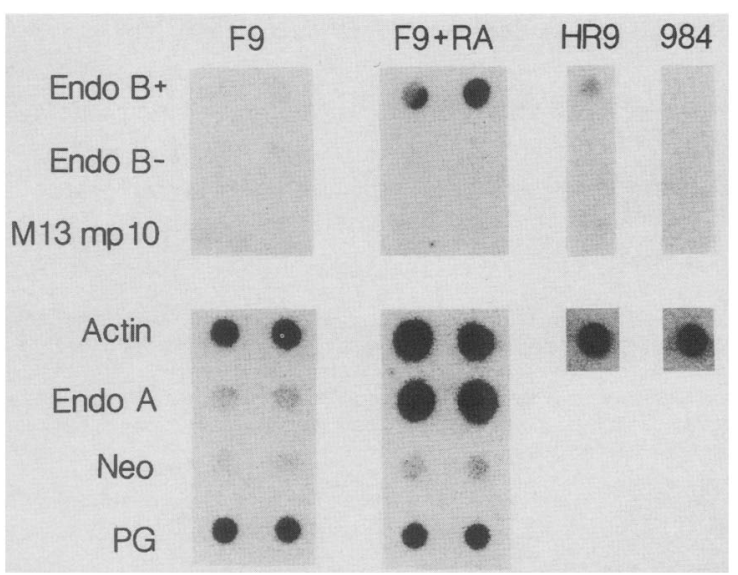

Figure 5. Nuclear run-on analysis of Endo B expression. Nuclei were isolated from F9 EC cells (F9), F9 cells that had been induced to differentiate by exposure to $1 \mu \mathrm{M}$ retinoic acid for 4 days (F9+RA), HR9 parietal endodermal cells (HR9), or 984 myoblasts (984) and permitted to elongate previously initiated RNA transcripts in the presence of [ ${ }^{32}$ P|UTP. The radioactive RNAs were purified and hybridized to $5 \mu \mathrm{g}$ of the denatured DNAs indicated at the left of the figure, which had been immobilized on nitrocellulose filters. After 4 days of hybridization, RNase treatment, and washing, the filters were exposed to film in the presence of an intensifier screen. (Endo $B+$ ) M13 singlestranded DNA containing the noncoding strand of the Endo B cDNA from nucleotide 461 to 1456 , which will hybridize to Endo B mRNA; (Endo B-) M13 single-stranded DNA containing the coding strand of the same portion of the Endo $B$ cDNA as Endo B $+(\mathrm{M} 13 \mathrm{mpl0})$ control M13mpl0 singlestranded DNA containing no additional sequences; (Actin) human $\beta$-actin cDNA plasmid pHFßA-1 (Ponte et al. 1984); (Endo A) $\alpha$-1 Endo A pseudogene plasmid (Vasseur et al. 1985); (Neo) control Sp 65 plasmid containing a portion of the Tn 5 neo gene; (PG) rat proteoglycan plasmid PG-6 (Bourdon et al. 1987) plasmid.

able fragment of greater than $1 \mathrm{~kb}$, which was not observed. We conclude that in addition to most or all of the CCGG sequences located in the first exon, at least some of the same sites upstream of exon I are not methylated in F9 or HR9 cells. In contrast, the $\beta 3, \beta 4, \beta 5$ genes are resistant to digestion with $\mathrm{HpaII}$, and additional experiments confirmed the same result for the $\beta 2$ gene. Digestion of the same EcoRI-digested DNAs with MspI shows that restriction sites for MspI or HpaII (CCGG) are present within or close to all four of the Endo B genes. Thus, the $\beta 1$ gene in F9 and HR9 cells is unique among the Endo B genes in being sensitive to HpaII digestion, most likely because of undermethylation of the internal $\mathrm{C}$ of a number of HpaII sites, some of which are located $5^{\prime}$ to the first exon. The $\beta 1$ gene in either STO or 984 cells is substantially resistant to digestion by HpaII and is thus methylated to much greater extent than in HR9 or F9 cells.

From the results shown in Figure 7, it is clear that the $5^{\prime}$ end of the $\beta 1$ gene is undermethylated in cells that express Endo $B$ or have the potential to express the gene after differentiation but is nearly completely methylated in fibroblasts and myoblasts. The identification of an
HTF-like region immediately upstream of the transcriptional start site and the conservation of a similar region of $\sim 200 \mathrm{bp}$ immediately upstream of the K18 gene (Kulesh and Oshima 1988) reinforces the possibility that differential methylation may be functionally important in limiting the expression of these keratins to simple epithelial cells. If this is the case, these keratins could represent one of the first examples of differential utilization of HTF islands that normally appear to be important for constitutively expressed genes (Bird 1986).

\section{Expression of Endo B and K18 in cellular hybrids}

To test for the presence of possible trans-acting negative regulatory activities of Endo B, mouse fibroblasts were fused with HeLa cells, which express the homologous $\mathrm{K} 18$ gene, and hybrids were isolated for protein and DNA analysis. Long-term hybrids instead of hetero-

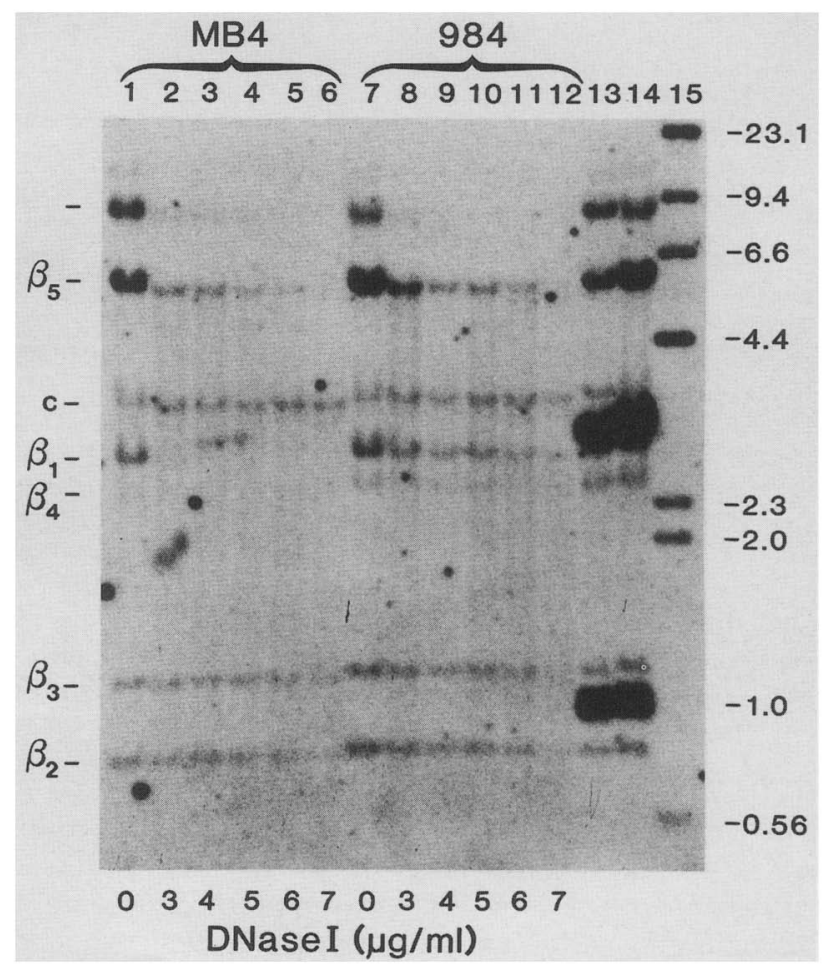

Figure 6. DNase sensitivity of Endo B genes in nuclei of endodermal and myoblast cells. Nuclei from MB4 endodermal cells (lanes 1-6) or T984cl10 myoblasts (lanes 7-12) were suspended at a concentration that resulted in an $A_{260}$ of 20 in $1 \mathrm{M} \mathrm{NaOH}$ and digested with the indicated concentrations of DNase I (bottom) for $10 \mathrm{~min}$ at $37^{\circ} \mathrm{C}$. The reaction was stopped by the addition of EDTA, SDS, and proteinase K. After organic solvent extraction and digestion with EcoRI, the samples were separated in a $0.5 \%$ agarose gel, transferred to nitrocellulose, and hybridized to nick-translated Endo B cDNA. The Endo B genes are labeled on the left, and size markers are indicated on the right (in kb). (Band c) A small amount of control plasmid DNA added after digestion with DNase that permits evaluation of the loading and transfer efficiency. Lanes 13 and 14 contained samples 1 and 7, respectively, with $20 \mathrm{pg}$ of additional Endo B cDNA to monitor the restriction enzyme digestion. 


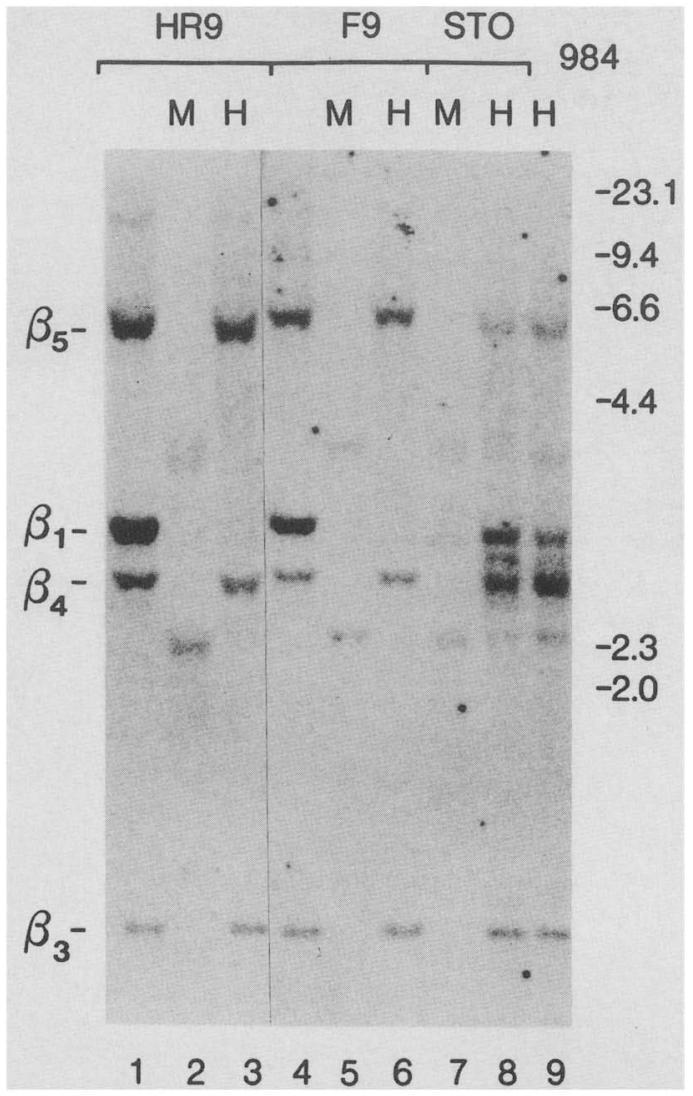

Figure 7. Differential methylation of the Endo B $\beta 1$ gene. DNAs isolated from mouse HR9 parietal endodermal cells (lanes 1-3), F9 EC cells (lanes 4-6), STO fibroblasts (lanes 7 and 8), or 984 myoblasts (lane 9) were digested with EcoRI alone (lanes 1 and 4), or in combination with MspI (M) (lanes 2, 5, and 7) or HpaII (H) (lanes 3, 6, 8, and 9). The digests were separated by agarose gel electrophoresis, transferred to nitrocellulose, and hybridized to an RNA probe corresponding to the first $461 \mathrm{nu}-$ cleotides of the Endo B cDNA. Final washes were at $50^{\circ} \mathrm{C}$. Individual Endo $B$ genes are indicated on the left, and size markers are indicated on the right (in $\mathrm{kb}$ ). Note that the $\beta 3, \beta 4$, and $\beta 5$ genes are resistant to digestion with HpaII in all cell lines. However, the $\beta 1$ gene is sensitive to digestion with HpaII only in HR9 and F9 cells.

karyon analyses were necessary for this study because of the extremely slow turnover of Endo B intermediate filaments and the difficulty in distinguishing Endo $B$ and $\mathrm{K} 18$ by immunofluorescent methods. Figure $8 \mathrm{~A}$ shows the result of immunoprecipitation analysis of a subset of all the hybrids analyzed. Three of the four hybrids shown continue to express K18, and none activates Endo B. The lack of expression of Endo B was not due to the absence of the Endo B $\beta 1$ gene in these hybrids, because Southern analysis confirmed the presence of the gene in these cells $16.5-\mathrm{kb}$ band, Fig. 8B, lane 12; additional data not shown). The varying level of expression of K18 correlates well with the presence of the active $\mathrm{K} 18$ gene sequences found in the hybrids, as shown in Figure $8 \mathrm{~B}$. The characterization of the gene coding for K18 (Kulesh and Oshima 1988) permitted the identification of a diagnostic 1.7-kb BamHI fragment containing sequences coding for the central portion of $\mathrm{K} 18$. This fragment was not detected in hybrid HeST 7.1 (Fig. 8B, lane 6), was barely detectable in HeST 3.7 (lane 5), and was present in higher amounts in HeST 7.5 (lane 9) and HeST 9.6 (lane 10). Thus, there is a direct relationship between the presence of the coding K18 gene and K18 protein synthesis. Further analysis of the degree of K18 protein synthesis in the other HeST hybrids investigated in Figure 8B confirmed this relationship (data not shown). The results provide no evidence for trans-acting negative regulators of the Endo B gene in mouse fibroblasts that could silence the homologous $\mathrm{K} 18$ gene. In addition, the silent Endo B gene in fibroblasts is not expressed even in a cellular environment that supports the expression of the homologous human gene.

To test whether the results of the analysis of the HeST hybrids were due to species-specific effects, hybrids were constructed between two mouse cell lines, which differed in their expression of Endo B. The isolation of authentic hybrids between two cells of the same species depends critically upon a double selective system that excludes the growth of both parents and the isolation of hybrids at sufficiently high frequency to make improbable the isolation of rare parental variants resistant to the selective conditions. Proliferating hybrids of HR9 endodermal cells and STO fibroblasts were found at a frequency of $\sim 1 \times 10^{4}$, whereas the frequency of variant parental cells was $\leqslant 1 \times 10^{-6}$. All four hybrids isolated from the fusion of HR9 and STO cells and examined in detail continued to express Endo B protein (Fig. 8C). These results reinforce the conclusion that STO fibroblasts do not appear to contain trans-acting regulatory activities that can suppress Endo B expression.

\section{Conclusions}

Endo B and its complementary type-II keratin, Endo A, which are first expressed at the 4-8 cell stage of development (Oshima et al. 1983; Duprey et al. 1985; Chisholm and Houliston 1987) are the first intermediate filament proteins to be expressed during mouse embryogenesis (Brulet et al. 1980; Jackson et al. 1980; Paulin et al. 1980; Oshima et al. 1983). This appears to be the only time when Endo B is expressed in the mouse germ line. By the early blastocyst stage, these proteins are expressed almost exclusively in the trophectoderm (Chisholm and Houliston 1987). Mouse EC cells do not express Endo B. However, human EC cells, which appear to be representative of a developmental stage equivalent to or even earlier than mouse EC cells, already express the homologous human gene, K18. This implies that very early human and mouse embryos differ in their expression of these homologous genes even though adult tissue expression is equivalent or identical. The larger number of genes similar to Endo B found in primate DNAs (Fig. 1) may reflect this difference in early developmental expression. Expression of K18 in the equivalent of the mouse inner cell mass would provide a target for retrovirus-mediated pseudogene generation in the germ line (Linial 1987). The extremely limited time 
Oshima et al.

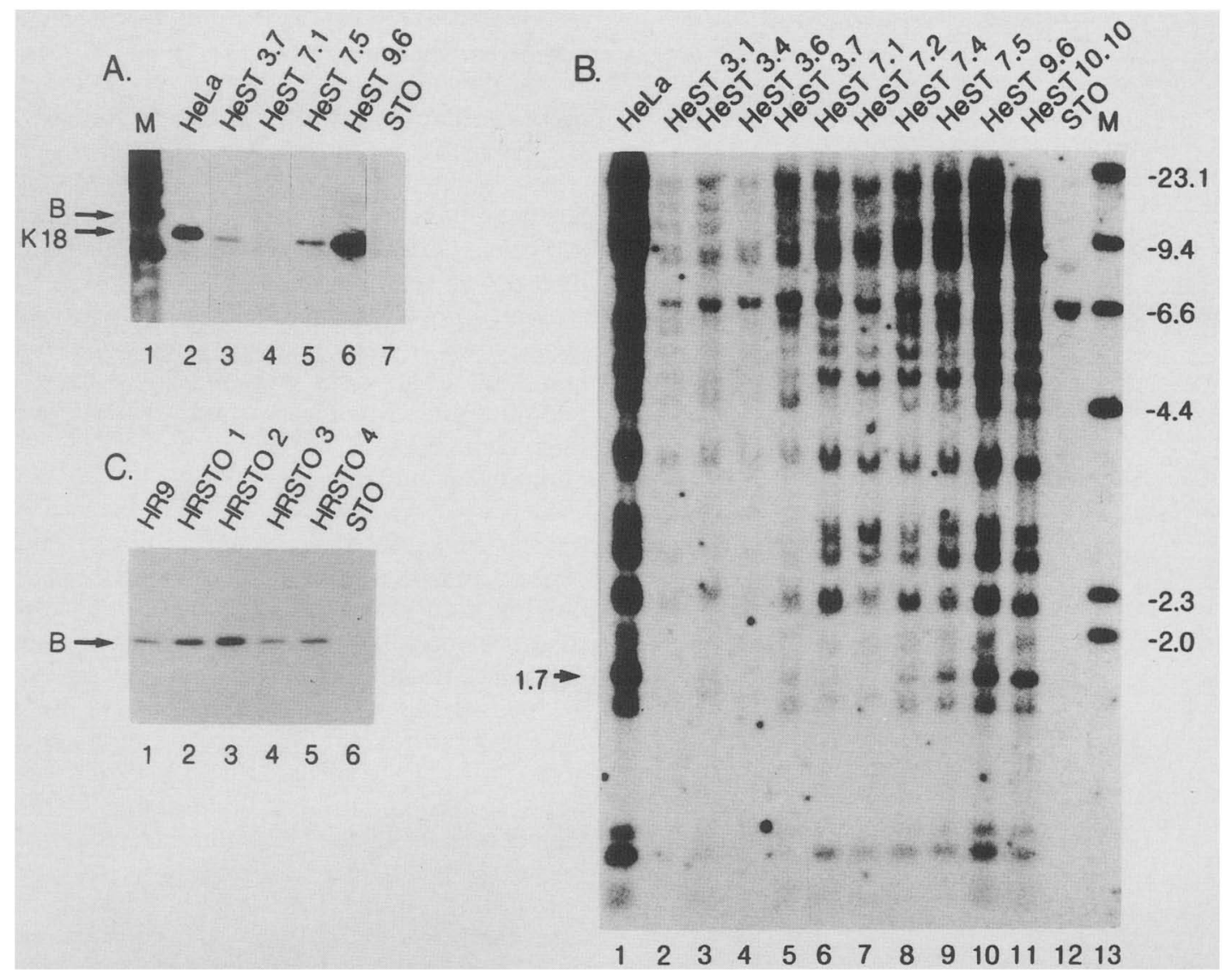

Figure 8. Expression of Endo B and K18 in cellular hybrids. Somatic cell hybrids were constructed and analyzed for the synthesis of Endo $\mathrm{B}$ and the homologous human protein $\mathrm{K} 18$ by immunoprecipitation $\mid A$ and $C \mid$ or for the presence of Endo $\mathrm{B}$ and $\mathrm{K} 18$ genes by the method of Southern (1975) (B). $(A)^{35}$ S-methionine-labeled cell lysates of HeLa cells (lane 1) or STO mouse fibroblast (lane 7) parental cells and hybrid clones derived from the fusion of the two parental cells (HeST 3.7, 7.1, 7.5, and 9.6) were immunoprecipitated with Endo B antiserum. The immunoprecipitates were separated by acrylamide gel electrophoresis in the presence of SDS and detected by fluorography. $(B)$ Position of Endo $B_{;}(\mathrm{K} 18)$ position of keratin $18 ;(\mathrm{M})$ mouse endodermal cytoskeletal protein size markers. $(B)$ Southern analysis of DNA from the HeLa and STO parental cell lines and from HeST hybrids. All DNAs were digested with BamHI, and the filter was hybridized with nick-translated pK187 K18 cDNA plasmid, which detects both K18 and Endo B genes. Final wash was performed at $55^{\circ} \mathrm{C}$ in $0.1 \times \mathrm{SSC}, 0.5 \%$ SDS. The filter was exposed for 6 days with two intensifier screens. Size markers are indicated on the right (in kb). $(\rightarrow \mid$ The $1.7-\mathrm{kb}$ fragment corresponding to the middle portion of the K18 gene. Note the presence of the $\sim 6.5-\mathrm{kb}$ mouse Endo B gene detected in STO DNA (lane 12) and all HeST hybrids, with the possible exception of HeST 10.10. (C) Immunoprecipitation analysis of Endo B synthesis in cellular hybrids derived from the fusion of HR9 endodermal cells (lane 1) and STO fibroblasts (lane 6). Endo B protein was detected by immunoprecipitation, as described for panel $A$. Note that all HR $\times$ STO hybrids (HRSTO 1-6, lanes 2-5) continue to express Endo B.

during which the germ line of rodents expresses Endo B could severely limit the incorporation of pseudogenes into the germ line. The acquisition of the differences in the very early developmental expression of Endo B and $\mathrm{K} 18$ may be coincident with the divergence of primates from other mammals.

The presence of five genes related to Endo B in the mouse genome requires the identification of the coding gene for detailed investigations of the regulation of Endo B. We have shown previously that tissues as diverse as parietal endoderm and liver express Endo B proteins that are indistinguishable in electrophoretic mobility, antigenicity, and peptide pattern (Trevor and Oshima 1985). In addition, the $5^{\prime}$ end of the Endo B mRNAs expressed in liver and parietal endoderm are identical, as judged by primer extension analysis (Trevor and Oshima 1985).
Several different results indicate that the Endo $B \beta 1$ gene is the single mouse Endo $B$ gene transcriptionally active in tissues as diverse as parietal endoderm and liver. The DNA sequence of the first exon of $\beta 1$, including the 5 'untranslated leader, matches the Endo B cDNA exactly (Fig. 4). The $\beta 1$ gene is distinguished from the other mouse Endo $B$ genes in the stability of hybrids formed with a cDNA probe (Fig. 2A), its sensitivity to digestion by DNase I in chromatin from cells that express the gene (Fig. 6), and in its methylation state (Fig. 7). Finally, the compact structure of the regions of the isolated $\beta 2, \beta 3$, and $\beta 5$ genes that hybridize to the Endo B cDNA is consistent with the expected structure of processed pseudogenes. DNA sequence divergence, as judged by restriction enzyme site mapping or direct determination of the DNA sequence of portions of the $\beta 2$ gene, indicates that 
none of these three codes for the parietal endodermal Endo B mRNA. Similarly, the weak hybridization of the $\beta 4$ putative gene and its hypermethylated state make it an unlikely candidate for an active Endo B gene fragment. We conclude that the cloned 3-kb EcoRI fragment of the $\beta 1$ gene represents the $5^{\prime}$ end of the single Endo B gene active in extraembryonic endoderm and liver.

The differential expression of Endo B in different cell types appears to be due to transcriptional regulation (Fig. 5). However, at least two different methods of controlling transcription of the Endo $\mathrm{B}$ gene are evident. In fibroblasts or myoblasts that do not express Endo B, the $5^{\prime}$ end of the $\beta 1$ gene is both methylated (Fig. 7) and in a relatively DNase I-resistant chromatin state (Fig. 6). This silent state appears to be quite stable because fusion of a fibroblast with HeLa cells, which express the homologous human protein, does not lead to the activation of Endo B (Fig. 8). In addition, no evidence for transacting negative regulation of Endo B was found in either these hybrids or hybrids made from the fusion of mouse endodermal and fibroblast cells. We have shown recently that a transfected homologous human gene, K18, can be expressed in mouse fibroblasts from its own promoter while the endogenous Endo B gene remains silent (Kulesh and Oshima 1988). This result both reinforces our conclusion concerning the stability of the inactive state of the Endo B gene in mouse fibroblasts and suggests that the interaction of trans-acting factors with the promoters of these genes is not the principal reason for the differential expression of these keratins in fibroblasts and permissive cells. The demonstration that the Endo B gene in myoblasts can be activated by treatment with 5-azacytidine (Darmon 1985), a treatment that results in substantial demethylation of CG dinucleotides (Jones and Taylor 1980), is supportive of a direct role for methylation in the cis-acting negative regulation of Endo B in fibroblasts or myoblasts. However, it is possible that the methylation state of the Endo $B \beta 1$ gene only reflects the inactive state and is not necessarily causal. Similar considerations must be given the altered chromatin state of the $\beta 1$ gene in different cell types. It may now be possible to map sequences of the K18 and Endo B $\beta 1$ genes necessary for the establishment of the stable inactive state found in fibroblasts by introducing recombinant constructions into pluripotent mouse EC cells or embryos and characterizing the activity, methylation status, and chromatin state of the constructions in differentiated cell types derived from the stem cells.

Although both undermethylation and a nuclease-sensitive chromatin state of the Endo B $\beta 1$ gene are correlated with activity in endodermal cells, they are not sufficient to permit expression in all cell types because the $\beta 1$ gene in EC cells is both sensitive to nuclease and undermethylated but is not expressed. Unlike fibroblasts, EC cells do not express transfected K18 genes efficiently (Kulesh and Oshima 1988). EC cells that have the potential of differentiating to cells that express Endo B appear to have an additional mechanism of suppressing transcription of the gene. This block may be related to recently reported evidence for a labile inhibitor of Endo A transcription in PCC4 EC cells /Cremisi and Duprey 1987). The sequence of the $5^{\prime}$ end of the $\beta 1$ gene revealed an interesting region of the first exon that might be involved in this regulation. At nucleotide 176, a region very similar to the tRNA-binding site of Moloney murine leukemia virus is found. Recently, this region of the virus has been implicated in the block to viral RNA expression in EC cells (Barklis et al. 1986; Loh et al. 1987; Weiher et al. 1987). It will be of great interest to determine whether this or other regions of the Endo B $\beta 1$ gene is involved in the suppression of Endo B expression during very early development.

\section{Methods}

\section{Cell culture}

All cell lines and culture conditions have been described previously (Oshima 1981). Somatic cell hybrids between HeLa cells and STO mouse fibroblasts (HeST hybrids) and HR9 parietal endodermal cells and STO cells (HRSTO hybrids) were constructed as described previously (Oshima et al. 1981; Howe and Oshima 1982). HRSTO hybrids were selected in DME medium supplemented with HAT (100 $\mu \mathrm{M}$ hypoxanthine, $0.4 \mu \mathrm{M}$ aminopterin, $16 \mu \mathrm{M}$ thymidine) and $2 \mathrm{~mm}$ ouabain. HeST hybrids were selected in HAT medium containing $5 \times 10^{-6} \mathrm{M}$ ouabain. Primary isolates were subcloned to ensure the absence of contaminating parental cells due to metabolic cooperation. Endo B protein synthesis was measured by immunoprecipitation, as described previously (Oshima 1982).

\section{Molecular probes}

Endo B probes were prepared either by nick translation (Meinkoth and Wahl 1984) of the pUC9B7 Endo B cDNA (Singer et al. $1986)$ or in vitro transcription with bacteriophage RNA polymerases. A HindIII-EcoRI 487-bp fragment of the Endo B cDNA that represents the first 461 nucleotides of the Endo B mRNA was subcloned in the SP64 vector (Promega, Madison, Wisconsin). The EcoRI-digested plasmid was transcribed with SP6 polymerase in the presence of [32P]GTP (Melton et al. 1984) to generate a truncated Endo B mRNA probe.

The transcriptional start site of the Endo B $\beta 1$ gene was mapped by the S1 protection method. A 658-bp fragment of the SK3112 plasmid derived from the SstI site at nucleotide -562 to the EcoRV site at nucleotide 196 was subcloned into M13mp18 that had been digested with SstI and Hincll. The sequencing primer and the Klenow fragment of DNA polymerase was used to generate a single-stranded radioactive probe that protected the first 196 nucleotides of Endo B mRNA (Kulesh and Oshima 1988).

\section{Isolation of Endo $B$ genes}

The BALB/c mouse embryo genomic library in Charon 4A (Maki et al. 1980) and the strain 129 mouse liver library in EMBL3A were gifts from R. Maki (La Jolla Cancer Research Foundation). Philip Leder (Harvard Medical School) provided the Charon 28 mouse embryo DNA library. The EMBL3 library of C57BL/6 T-cell DNA (provided by R. Maki) was prepared by standard methods (Maniatis et al. 1982) after partial digestion with $M b o$. All were screened by the method of Benton and Davis (1977), using either nick-translated Endo B cDNA or an RNA probe of the first 461 nucleotides of the Endo B cDNA. To obtain the Endo B $\beta 1$ gene fragment, HR9 mouse parietal endo- 
dermal DNA was digested with EcoRI, size fractionated by agarose gel electrophoresis, and recovered with powdered glass (Vogelstein and Gillespie 1979). The DNA of a fraction that hybridized strongly to a sense RNA probe of the $5^{\prime}$ end of the Endo $B$ cDNA was cloned into $\lambda$ ZAP (Stratagene, La Jolla, California) and packaged and screened without amplification. K802 cells (Wood 1966) were used as host. Approximately 400,000 pfu were screened by transfer to nitrocellulose and hybridization with the 461-nucleotide RNA probe. After two additional rounds of purification and screening, eight of nine isolates were rescued from the phage as plasmids by coinfection of XL-1 cells with the individual $\lambda Z$ ZAP isolates and R48 helper phage according to the suppliers instructions. Five of the isolates grew slowly, and gel analysis of the supernatants of these cultures revealed varying amounts of presumptive helper phage DNA, which appeared to correlate with their slower growth. Six of the rescued plasmids appeared to be very closely related by restriction enzyme mapping and Southern analysis. One of these was analyzed in detail after transfection into DH-1 cells to ensure the absence of helper phage and is designated SK3112. This plasmid represents $\sim 3 \mathrm{~kb}$ of the Endo $\mathrm{B} \beta \mathrm{l}$ gene inserted in the EcoRI polylinker site of the Bluescript SK M13m vector (Stratagene, La Jolla, California).

\section{DNA sequence}

For DNA sequence determination, a 1.6-kb BamHI fragment of SK3112, derived from sites located at -927 and 20 nucleotides downstream of the 3' EcoRI cloning site (nucleotide 648), was subcloned into $\mathrm{M} 13 \mathrm{mpl} 8$ in both orientations. Ordered deletions were constructed utilizing exonuclease III and nuclease S1 (Henikoff 1984) after digestion with both SphI and XbaI. The sequence was determined by the dideoxy nucleotide chain termination method (Sanger et al. 1977) using modified T7 DNA polymerase (Sequenase, U.S. Biochemical) and ${ }^{35}$ S-labeled dATP (Biggin et al. 1983). The final sequence was assembled from data of 13 different deletions for one strand and 15 for the opposite strand, using the GEL program of the BIONET computer system (Intelligenetics, Mountain View, California).

\section{DNase digestion of Endo B genes}

Nuclei were prepared by rinsing cell cultures three times in cold PBS, scraping the cells into $25 \mathrm{ml}$ of cold lysis buffer $[0.25$ M sucrose, $0.5 \%$ NP-40 nonionic detergent, $10 \mathrm{~mm}$ Tris- $\mathrm{HCl}$ (pH 7.2), $10 \mathrm{~mm} \mathrm{NaCl}, 5 \mathrm{~mm} \mathrm{MgCl}_{2}, 0.1 \mathrm{~mm}$ EGTA, phenylmethylsulfonyl fluoride (PMSF)] and low-speed centrifugation at $4^{\circ} \mathrm{C}$. The nuclei were resuspended in lysis buffer with use of a Dounce homogenizer and centrifuged through a cushion of $30 \%$ sucrose in $10 \mathrm{~mm}$ Tris $-\mathrm{HCl}(\mathrm{pH} 7.2), 10 \mathrm{mM} \mathrm{NaCl}$, and 3 $\mathrm{mM} \mathrm{MgCl}$. The nuclei were then suspended in the same buffer without sucrose and containing $0.1 \mathrm{mM} \mathrm{CaCl}_{2}$ at an $\mathrm{A}_{260}$ of 20 (determined on an aliquot digested with micrococcal nuclease and dissolved in $1 \mathrm{M} \mathrm{NaOH}$ ), and digested for $10 \mathrm{~min}$ at $37^{\circ} \mathrm{C}$ with varying concentrations of protease-free DNase I (Otsuka and Price 1974). Digestion was stopped by the addition of EDTA to $10 \mathrm{~mm}$ and SDS and proteinase $\mathrm{K}$ to final concentrations of $1 \%$ and $200 \mu \mathrm{g} / \mathrm{ml}$, respectively. After incubation overnight at $37^{\circ} \mathrm{C}$, the DNA was purified by extraction with phenolchloroform, chloroform, and ether and was ethanol precipitated. Aliquots of DNA were digested with restriction enzyme and analyzed by the method of Southern (1975).

\section{Nuclear run-on analysis}

Nuclei were prepared as described by others (Wang et al. 1985), with modifications. All cells were grown in roller bottles and washed with phosphate-buffered saline while still attached, scraped into Buffer A [0.3 M sucrose, $10 \mathrm{mM}$ Tris- $\mathrm{HCl}(\mathrm{pH} 7.2)$, $5 \mathrm{mM} \mathrm{MgCl}, 0.1 \mathrm{mM} \mathrm{K} 2$ EGTA, $0.4 \%$ NP-40, $0.5 \mathrm{~mm}$ dithiothreitol (DTT)], and recovered by low-speed centrifugation. After homogenization and washing once, as described (Wang et al. 1985), the nuclei were treated with protease and DNase-free RNase $(20 \mu \mathrm{g} / \mathrm{ml})$ for $5 \mathrm{~min}$ at $20^{\circ} \mathrm{C}$, washed twice more by centrifugation through a sucrose cushion, washed once in $40 \%$ glycerol, $50 \mathrm{mM}$ Tris- $\mathrm{HCl}(\mathrm{pH} 8.3), 5 \mathrm{~mm} \mathrm{MgCl}_{2}$, and $0.1 \mathrm{~mm}$ EDTA, resuspended in the same buffer at $2 \times 10^{8}$ nuclei $/ \mathrm{ml}$, and stored at $-85^{\circ} \mathrm{C}$. Transcription reactions were performed in $20 \%$ glycerol, $25 \mathrm{~mm}$ Tris- $\mathrm{HCl}$ ( $\mathrm{pH} 8.3$ ), $3 \mathrm{mM} \mathrm{MgCl}_{2}, 70$ $\mathrm{mm} \mathrm{KCl}, 0.5 \mathrm{~mm} \mathrm{MnCl}_{2}, 2.5 \mathrm{~mm} \mathrm{DTT}, 1 \mathrm{U} / \mu \mathrm{l}$ RNasin RNase inhibitor (Promega), $0.8 \mathrm{mM} \mathrm{ATP}, 0.4 \mathrm{mM}$ CTP and GTP, $8 \mu \mathrm{M}$ $\mathrm{UTP}$, and $250 \mu \mathrm{Ci}$ of $\left[\alpha^{-32} \mathrm{P}\right] \mathrm{UTP}(800 \mathrm{Ci} / \mathrm{mm})$ in $200 \mu$ containing $2 \times 10^{7}$ nuclei for $10 \mathrm{~min}$ at $26^{\circ} \mathrm{C}$. Radioactive RNA was purified (Groudine et al. 1981) and hybridized to denatured DNA immobilized on nitrocellulose in $50 \%$ formamide, $5 \times$ SSPE, $0.1 \%$ SDS, $250 \mu \mathrm{g} / \mathrm{ml}$ salmon DNA, and $2 \times$ Denhardt's solution (Maniatis et al. 1982) at $42-60^{\circ} \mathrm{C}$ for 4 days. Filters were washed several times in $2 \times$ SSPE, $0.1 \%$ SDS at room temperature, rinsed in $2 \times \mathrm{SSPE}$, and treated with $10 \mu \mathrm{g} / \mathrm{ml}$ RNase $A$ in $0.15 \mathrm{M} \mathrm{NaCl}, 10 \mathrm{~mm}$ Tris- $\mathrm{HCl}(\mathrm{pH} 7.2)$ and $1 \mathrm{~mm}$ EDTA for $30 \mathrm{~min}$ at room temperature and, finally, washed in $0.1 \times$ SSPE, $0.1 \%$ SDS at $50-65^{\circ} \mathrm{C}$. Filters were then exposed to film at $-85^{\circ} \mathrm{C}$ with an intensifier screen.

\section{Acknowledgments}

The authors thank R. Maki (La Jolla Cancer Research Foundation) for mouse DNA libraries, extensive discussions, and technical advice; Philip Leder (Harvard Medical School) for the mouse embryonic DNA library; Phillip Singer for help in isolating and sequencing part of the Endo B 32 gene; Leslie Abrams for technical assistance in determining the DNA sequence of the Endo B $\beta 1$ gene fragment; and Frank Fujimura and Elizabeth Mather (La Jolla Cancer Research Foundation) for their comments on the manuscript. We thank P. Gunning (Stanford University), M. Vasseur (Pasteur Institute, Paris), and M. Bourdon (La Jolla Cancer Research Foundation) for the actin, Endo A, and proteoglycan plasmids, respectively. K.T. and L.H.S. were supported, in part, by Postdoctoral Training grant T32 CA09497 and U.S. Public Health Service Fellowship F32 HD06594, respectively. This investigation was supported by U.S. Public Health Service grants CA33946 and CA42302 (R.G.O.) and GM23073 (O.A.R.) and Cancer Center Support grant P30 CA30199 awarded by the National Cancer Institute (Department of Health and Human Services).

\section{Note}

Sequence data described in this paper have been submitted to the EMBL/GenBank Data Libraries under the accession number Y00217.

\section{References}

Barklis, E., R.C. Mulligan, and R. Jaenisch. 1986. Chromosomal position or virus mutation permits retrovirus expression in embryonal carcinoma cells. Cell 47: 391-399.

Benton, W.D. and R.W. Davis. 1977. Screening $\lambda$ gt recombinant clones by hybridization to single plaques in situ. Science 196: $180-182$. 
Biggin, M.D., T.J. Gibson, and G.F. Hong. 1983. Buffer gradient gels and ${ }^{35} \mathrm{~S}$ label as an aid to rapid sequence determination. Proc. Natl. Acad. Sci. 80: 3963-3965.

Bird, A. 1986. CpG-rich islands and the function of DNA methylation. Nature 321: 209-213.

Bourdon, M.A., M. Shiga, and E. Ruoslahti. 1987. Gene expression of the chondroitin sulfate proteoglycan core protein PG19. Mol. Cell. Biol. 7: 33-40.

Brulet, P., C. Babinet, R. Kemler, and F. Jacob. 1980. Monoclonal antibodies against trophectoderm-specific markers during mouse blastocyst formation. Proc. Natl. Acad. Sci. 77: 4113-4117.

Chisholm, J.C. and E. Houliston. 1987. Cytokeratin filament assembly in the preimplantation mouse embryo. Development 101: $565-582$.

Cremisi, C. and P. Duprey. 1987. A labile inhibitor blocks endo A gene transcription in murine undifferentiated embryonal carcinoma cells. Nucleic Acids Res. 15: 6105-6116.

Damjanov, I. and P.W. Andrews. 1983. Ultrastructural differentiation of a clonal human embryonal carcinoma cell line in vitro. Cancer Res. 43: 2190-2198.

Damjanov, I., R.K. Clark, and P.W. Andrews. 1985. Expression of keratin polypeptides in human embryonal carcinoma cells. In Intermediate filaments (ed. E. Wang, D. Fischman, R.K.H. Liem, and T.T. Sun|, pp. 732-733. New York Academy of Sciences, New York.

Darmon, M. 1985. Coexpression of specific acid and basic cytokeratins in teratocarcinoma-derived fibroblasts treated with 5-azacytidine. Dev. Biol. 110: 47-52.

Duprey, P., D. Morello, M.Vasseur, C. Babinet, H. Condamine, P. Brulet, and F. Jacob. 1985. Expression of the cytokeratin endo A gene during early mouse embryogenesis. Proc. Natl. Acad. Sci. 82: 8538-8539.

Dynan, W.S. and R. Tjian. 1985. Control of eukaryotic messenger RNA synthesis by sequence-specific DNA-binding proteins. Nature 316: 774-778.

Franke, W.W., H. Denk, R. Kalt, and E. Schmid. 1981a. Biochemical and immunological identification of cytokeratin proteins present in hepatocytes of mammalian liver tissue. Exp. Cell Res. 131: 299-318.

Franke, W.W., D.L. Schiller, R. Moll, S. Winter, E. Schmid, and I. Engelbrecht. 1981b. Diversity of cytokeratins. J. Mol. Biol. 153: 933-959.

Groudine, M., M. Peretz, and H. Weintraub. 1981. Transcriptional regulation of hemoglobin switching in chicken embryos. Mol. Cell. Biol. 1: 281-288.

Grover, A., S.A. Edwards, M. Bourdon, and E.D. Adamson. 1988. Proteoglycan-19, laminin and collagen type IV production is correlated with the levels of mRNA in F9 cell aggregates differentiating in the presence or absence of cyclic AMP. Differentiation 36: 138-144.

Henikoff, S. 1984. Unidirectional digestion with exonuclease III creates targeted breakpoints for DNA sequencing. Gene 28: $351-359$.

Howe, W.E. and R.G. Oshima. 1982. Coordinate expression of parietal endodermal functions in hybrids of embryonal carcinoma and endodermal cells. Mol. Cell. Biol. 2: 331-337.

Jackson, B.W., C. Grund, E. Schmid, K. Burke, W. Franke, and K. Illmensee. 1980. Formation of cytoskeletal elements during mouse embryogenesis: Intermediate filaments of the cytokeratin type and desmosomes in preimplantation embryos. Differentiation 17: 161-179.

Jones, P.A. and S.M. Taylor. 1980. Cellular differentiation, cytidine analogs and DNA methylation. Cell 20: 85-93.

Kemler, R., P. Brulet, M.T. Schnebelen, J. Gaillard, and F. Jacob. 1981. Reactivity of monoclonal antibodies against interme- diate filament proteins during embryonic development. $J$. Embryol. Exp. Morphol. 64: 45-60.

Kulesh, D.A. and R.G. Oshima. 1988. Cloning of the human keratin 18 gene and its expression in non-epithelial mouse cells. Mol. Cell. Biol. 8: 1540-1550.

Lazarides, E. 1980. Intermediate filaments as mechanical integrators of cellular space. Nature 283: 249-256.

- 1982. Intermediate filaments: A chemically heterogeneous, developmentally regulated class of proteins. Annu. Rev. Biochem. 51: 219-250.

Linial, M. 1987. Creation of a processed pseudogene by retroviral infection. Cell 49: 93-102.

Loh, T.P., L.L. Sievert, and R.W. Scott. 1987. Proviral sequences that restrict retroviral expression in mouse embryonal carcinoma cells. Mol. Cell. Biol. 7: 3775-3784.

Maki, R., A. Traunecker, H. Sakano, W. Roeder, and S. Tonegawa. 1980. Exon shuffling generates an immunoglobulin heavy chain gene. Proc. Natl. Acad. Sci. 77: 2138-2142.

Maniatis, T., E.F. Fritsch, and J. Sambrook. 1982. Molecular cloning: A laboratory manual. Cold Spring Harbor Laboratory, Cold Spring Harbor, New York.

McKnight, G.S. and R.D. Palmiter. 1979. Transcriptional regulation of the ovalbumin and conalbumin genes by steroid hormones in chick oviduct. J. Biol. Chem. 254: 9050-9058.

Meinkoth, J. and G. Wahl. 1984. Hybridization of nucleic acids immobilized on solid supports. Anal. Biochem. 138: 267284.

Melton, D.A., P.A. Krieg, M.R. Rebagliati, T. Maniatis, K. Zinn, and M.R. Green. 1984. Efficient in vitro synthesis of biologically active RNA and RNA hybridization probes from plasmids containing a bacteriophage SP6 promoter. Nucleic Acids Res. 12: 7035-7055.

Moll, R., W.W. Franke, D.L. Schiller, B. Geiger, and R. Krepler. 1982. The catalog of human cytokeratins: Patterns of expression in normal epithelia, tumors and cultured cells. Cell 31: $11-24$.

Oshima, R.G. 1981. Identification and immunoprecipitation of cytoskeletal proteins from murine extra-embryonic endodermal cells. J. Biol. Chem. 256: 8124-8133.

- 1982. Developmental expression of murine extra-embryonic endodermal cytoskeletal proteins. J. Biol. Chem. 257: 3414-3421.

Oshima, R.G., J. McKerrow, and D. Cox. 1981. Murine embryonal carcinoma hybrids: Decreased ability to spontaneously differentiate as a dominant trait. $/$. Cell. Physiol. 109: 195-204.

Oshima, R.G., W.E. Howe, F.G. Klier, E.D. Adamson, and L.H. Shevinsky. 1983. Intermediate filament protein synthesis in preimplantation murine embryos. Dev. Biol. 99: 447-455.

Ohshima, Y. and Y. Gotoh. 1987. Signals for the selection of a splice site in pre-mRNA: Computer analysis of splice junction sequences and like sequences. $J$. Mol. Biol. 195: 247259.

Otsuka, A.S. and P.A. Price. 1974. Removal of protease from DNase 1 by chromatography over agarose with covalently attached lima bean protease inhibitor. Anal. Biochem. 62: $180-187$.

Paulin, D., C. Babinet, K. Weber, and M. Osborn. 1980. Antibodies as probes of cellular differentiations and cytoskeletal organization in the mouse blastocyst. Exp. Cell Res. 130: $297-304$.

Ponte, P., S.Y. Ng, J. Engel, P. Gunning, and L. Kedes. 1984. Evolutionary conservation in the untranslated regions of actin mRNAs: DNA sequence of a human beta-actin cDNA. Nucleic Acids Res. 12: 1687-1696.

Sanger, F., S. Nicklen, and A.R. Coulson. 1977. DNA se- 
Oshima et al.

quencing with chain-terminating inhibitors. Proc. Natl. Acad. Sci. 74: 5463-5467.

Schiller, D., W.W. Franke, and B. Geiger. 1982. A subfamily of relatively large and basic cytokeratin polypeptides as defined by peptide mapping is represented by one or several polypeptides in epithelial cells. EMBO J. 1: 761-769.

Singer, P.A., K. Trevor, and R.G. Oshima. 1986. Molecular cloning and characterization of the Endo B cytokeratin expressed in preimplantation mouse embryos. J. Biol. Chem. 261: $538-547$.

Southern, E. 1975. Detection of specific sequences among DNA fragments separated by gel electrophoresis. I. Mol. Biol. 98: $503-517$.

Steinert, P.M. and D.A.D. Parry. 1985. Intermediate filaments: Conformity and diversity of expression and structure. Annu. Rev. Cell Biol. 1: 41-65.

Trevor, K. and R.G. Oshima. 1985. Preimplantation mouse embryos and liver express the same type I keratin gene product. J. Biol. Chem. 260: 15885-15891.

Vasseur, M., P. Duprey, P. Brulet, and F. Jacob. 1985. One gene and one pseudogene for the cytokeratin Endo A. Proc. Natl. Acad. Sci. 82: 1155-1159.

Vogelstein, B. and D. Gillespie. 1979. Preparative and analytical purification of DNA from agarose. Proc. Natl. Acad. Sci. 76: 615-619.

Wang, S.Y., G.J. LaRosa, and L.J. Gudas. 1985. Molecular cloning of gene sequences transcriptionally regulated by retinoic acid and dibutyryl cyclic AMP in cultured mouse teratocarcinoma cells. Dev. Biol. 107: 75-86.

Weiher, H., E. Barklis, W. Ostertag, and R. Jaenisch. 1987. Two distinct sequence elements mediate retroviral gene expression in embryonal carcinoma cells. J. Virol. 61: 2742-2746.

Wood, W.B. 1966. Host specificity of DNA produced by Escherichia coli: Bacterial mutations affected the restriction and modification of DNA. J. Mol. Biol. 16: 118-133. 


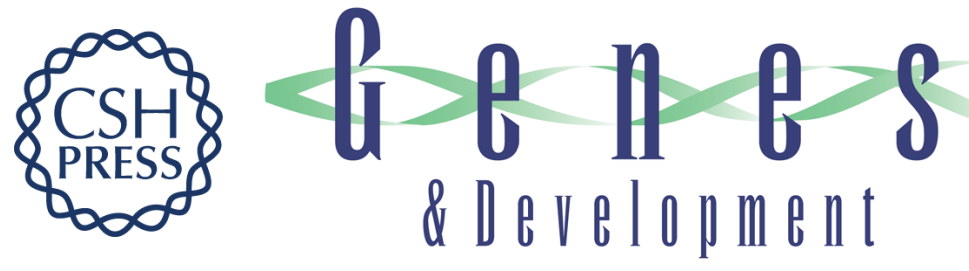

\section{Identification of the gene coding for the Endo B murine cytokeratin and its methylated, stable inactive state in mouse nonepithelial cells.}

R G Oshima, K Trevor, L H Shevinsky, et al.

Genes Dev. 1988, 2:

Access the most recent version at doi:10.1101/gad.2.5.505

References This article cites 50 articles, 20 of which can be accessed free at:

http://genesdev.cshlp.org/content/2/5/505.full.html\#ref-list-1

License

Email Alerting

Service

Receive free email alerts when new articles cite this article - sign up in the box at the top right corner of the article or click here.

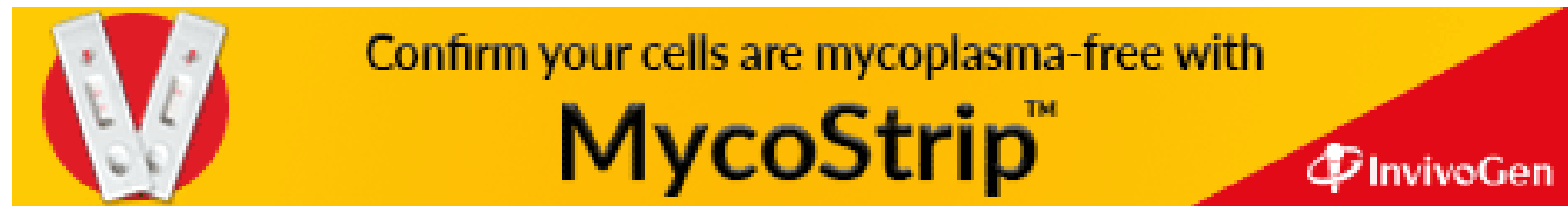

